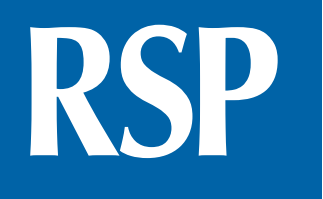

http://www.rsp.fsp.usp.br/
Revista de Saúde Pública

\title{
Cost of diseases related to alcohol consumption in the Brazilian Unified Health System
}

Evandro Silva Freire Coutinho', Luciana Bahia", Laura Augusta Barufaldi"', Gabriela de Azevedo Abreu'v, Thainá Alves Malhãov", Camila Ribeiro Pepe ${ }^{\mathrm{vI}}$, Denizar Vianna Araujo"

I Escola Nacional de Saúde Pública. Fundação Oswaldo Cruz. Rio de Janeiro, RJ, Brasil

" Departamento de Medicina Interna. Universidade do estado do Rio de Janeiro. Rio de Janeiro, RJ, Brasil

III Departamento de Vigilância de Doenças e Agravos Não Transmissíveis e Promoção da Saúde. Secretaria de Vigilância em Saúde. Ministério da Saúde. Brasília, DF, Brasil

Iv Instituto de Estudos em Saúde Coletiva. Universidade Federal do Rio de Janeiro. Rio de Janeiro, RJ, Brasil

$\checkmark$ Unidade Técnica de Alimentação, Nutrição e Câncer. Coordenação de Prevenção e Vigilância. Instituto Nacional de Câncer José Alencar Gomes da Silva. Rio de Janeiro, RJ, Brasil

${ }^{v 1}$ Medinsight Decisions in Health Care. São Paulo, SP, Brasil

\section{ABSTRACT}

OBJECTIVE: To estimate the direct costs associated to outpatient and hospital care of diseases related to alcohol consumption in the Brazilian Unified Health System.

METHODS: Attributable populational risks were estimated for the selected diseases related to the use of $25 \mathrm{~g}$ /day or more of ethanol (risk consumption), considering a relative risk $(\mathrm{RR}) \geq 1.20$. The RR estimates were obtained from three meta-analysis. The risk consumption rates of the Brazilian population $\geq 18$ years old were obtained by a national survey. Data from the Hospital Information System of SUS (HIS-SUS) were used to estimate the annual costs of the health system with the diseases included in the analysis.

Correspondence:

Evandro Silva Freire Coutinho

Escola Nacional de Saúde

Pública - Fiocruz

Rua Leopoldo Bulhões, 1480

Manguinhos

21041-210 Rio de Janeiro, RJ, Brasil

E-mail: esfcoutinho@gmail.com

Received: 21 Jul 2014

Approved: 20 Jul 2015

How to cite: Coutinho ESF, Bahia L, Barufaldi LA, Abreu GA, Malhão TA, Pepe CR, et al. Cost of diseases related to alcohol consumption in the Brazilian Unified Health System. Rev Saude Publica.

2016;50:28.

Copyright: This is an open-access article distributed under the terms of the Creative Commons Attribution License, which permits unrestricted use, distribution, and reproduction in any medium, provided that the original author and source are credited.
RESULTS: The total estimated costs for a year regarding diseases related to risk consumption were U\$8,262,762 (US\$4,413,670 and US\$3,849,092, for outpatient and hospital care, respectively).

CONCLUSIONS: Risk consumption of alcohol is an important economic and health problem, impacting significantly the health system and society.

DESCRIPTORS: Alcohol-Related Disorders, economics. Health Care Costs. Costs and Cost Analysis. Unified Health System. 


\section{INTRODUCTION}

Although alcohol consumption and related problems can vary around the world, the burden of alcohol-related diseases affects most countries. The World Health Organization $(\mathrm{WHO}, 2010)^{\mathrm{a}}$ states that the use of alcohol is one of the main risk factors for poor health, premature deaths, disabilities, and global burden of disease, compromising both individual and social development. The WHO also estimates that, in 2004, 2.5 million individuals worldwide died of alcohol-related causes, which represents around $4.0 \%$ of the total number of deaths $s^{\mathrm{a}}$. Thirteen percent of them were people aged between 15 and 29 years. Approximately $4.5 \%$ of the global burden of disease and injury is attributable to alcohol, although these figures can vary from $1.3 \%$ to $12.1 \%$ across the world 7 .

The cost of alcohol consumption to the health sector is not restricted to the treatment of alcohol dependence alone, but also to a set of alcohol-related diseases. ${ }^{4}$ Alcohol causes more than 30 diseases listed in the $10^{\text {th }}$ International Classification of Diseases (ICD-10), and works as a component cause for over 200 diseases $^{\mathrm{b}}$. The impact of alcohol use on these conditions depends on two aspects: the volume consumed and the pattern of drinking.

A systematic review ${ }^{9}$ reported that, despite the discrepancies in the estimation methods and cost components used across different studies, findings on the substantial economic burden of alcohol on society are consistent. The authors estimated that the economic burden of alcohol accounts for $0.5 \%$ to $5.4 \%$ of the gross domestic product. The socioeconomic development level of countries, regions, and individuals is inversely associated with the burden of alcohol-related diseases ${ }^{c}$. In order to estimate the global burden of harm related to alcohol, WHO classifies countries using a four-point risk scale (1 [low] to 4 [high]) according to the pattern of its alcohol consumption. Data have shown that this scale can be equated to morbid-mortality rates attributable to alcohol consumption. Brazil is classified as level $4^{6}$.

This study aimed to estimate the specific direct costs (medical costs) associated with outpatient and inpatient care of alcohol-related diseases in the Brazilian Unified Health System (SUS).

\section{METHODS}

To assess health care costs for alcohol-related diseases, it is necessary to apply the population attributable risk (PAR) for alcohol to the number of patients with a related disease. The population attributable risk is the proportion of the incidence of a disease in the population exposed to a particular risk factor that would, consequently, be eliminated if exposure was eliminated.

For PAR calculation, we selected diseases based on two criteria: (i) relative risk (RR) for alcohol consumption $\geq 1.20$, which included oropharyngeal cancer, esophageal cancer, laryngeal cancer, liver cancer, breast cancer, hypertension, liver cirrhosis, and chronic pancreatitis; and (ii) RR for alcohol consumption $\geq 1.10$ and $<1.20$, if the disease was considered a relevant public health problem because of its prevalence. No disease met this criterion.

The exposure category was $25 \mathrm{~g} /$ day or more of ethanol and the reference group was comprised of individuals referred to in the studies as abstemious.

We estimated PAR using Levin's formula ${ }^{5}$, defined as the proportion of all cases that would not have occurred if the exposure had been absent.

$$
P A R=\frac{P_{e}(R R-1)}{P_{e}(R R-1)+1}
$$

where $P e$ is the prevalence of exposure and $R R$ the relative risk.

We searched for meta-analyses presenting RR estimates associated with the presence of alcohol consumption. As well as identifying the most recent meta-analyses, we also looked 
dMinistério da Saúde,

Secretaria de Atenção à Saúde, Departamento de Regulação, Avaliação e Controle. Sistema de informações hospitalares do SUS - SIH/SUS. Brasília (DF):

Datasus; 2011. for large individual studies published after the search period covered by the meta-analyses. Literature was searched in Medline and Scopus databases. All the searches contained two blocks of concepts: one of the descriptors of exposure ("alcohol-related disorder"”, "alcohol drinking" "alcohol intake", "alcohol-related disease ${ }^{* ")}$ and one of descriptors related to the selected diseases.

The meta-analyses quality was evaluated using the Assessing the Methodological Quality of Systematic Reviews (AMSTAR) inventory ${ }^{8}$. The meta-analyses carried out by Barnardi et al. ${ }^{1}$ (2001), Corrao et al. ${ }^{2}$ (2004), and Islami et al. ${ }^{3}$ (2010) provided the necessary information on RR for PAR calculation (Table 1).

The prevalence rates of alcohol consumption in the adult population were obtained from a large national survey carried out by the Brazilian National Cancer Institute (INCA) in the 2002-2003 period ${ }^{\mathrm{d}}$. The study defined one drink for women ( $15 \mathrm{~g} /$ day of ethanol) and two drinks for men ( $30 \mathrm{~g} /$ day of ethanol) as hazardous consumption. Thus, we used the $\mathrm{RR}$ provided in the meta-analyses of $25 \mathrm{~g} /$ day ethanol, as this was closest to the category that the INCA survey referred to as hazardous consumption. The assumption behind this decision was that the distribution of alcohol use over $25 \mathrm{~g} /$ day of ethanol is expected to be skewed to the right, which means that most individuals that consume more than $25 \mathrm{~g} /$ day are closer to this value than to the other extreme of the distribution.

The study report did not provide data stratified by sex, as its main objective was to estimate the prevalence of tobacco use. The figures by sex used in our analysis were kindly provided by INCA. Data were unavailable for nine of the 26 state capitals of Brazil. The median of the proportion of hazardous consumption from other capitals in the same region was used to replace the missing information.

Table 1. Characteristics and relative risks (RR) from the studies used in the analysis, by included diseases.

\begin{tabular}{|c|c|c|c|c|c|c|c|}
\hline Disease & $\begin{array}{l}25 \text { g/day } \\
\text { RR }\end{array}$ & $\begin{array}{l}50 \text { g/day } \\
\text { RR }\end{array}$ & $\begin{array}{l}100 \mathrm{~g} / \text { day } \\
\text { RR }\end{array}$ & $\begin{array}{c}\text { Study } \\
\text { Meta-analysis* }\end{array}$ & $\begin{array}{l}\text { Period } \\
\text { covered }\end{array}$ & $\begin{array}{l}\mathrm{N} \text { and type of included } \\
\text { studies; Total sample size }\end{array}$ & AMSTAR \\
\hline $\begin{array}{l}\text { Oropharyngeal } \\
\text { cancer }\end{array}$ & $\begin{array}{l}1.86 \\
1.73\end{array}$ & $\begin{array}{l}3.11 \\
2.77\end{array}$ & $\begin{array}{l}6.45 \\
5.75\end{array}$ & $\begin{array}{l}\text { Corrao et al. }{ }^{2} \\
(2004) \\
\text { Bagnardi et al. }{ }^{1} \\
(2001)\end{array}$ & $\begin{array}{l}1966-1998 \\
1966-2000\end{array}$ & $\begin{array}{l}14 \mathrm{CC}, 01 \mathrm{CO} ; 4507 \\
25 \mathrm{CC}, 01 \mathrm{CO} ; 7954\end{array}$ & $\begin{array}{l}9 / 11 \\
4 / 11\end{array}$ \\
\hline $\begin{array}{l}\text { Esophageal } \\
\text { cancer }\end{array}$ & $\begin{array}{c}1.39 \\
\mathrm{~T}: 1.51 \\
\mathrm{M}: 1.43 \\
\mathrm{~F}: 1.52\end{array}$ & $\begin{array}{c}1.93 \\
\mathrm{~T}: 2.21 \\
\mathrm{M}: 1.98 \\
\mathrm{~F}: 2.24\end{array}$ & $\begin{array}{c}3.59 \\
\text { T: } 4.23 \\
\text { M: } 3.49 \\
\text { F: } 4.45\end{array}$ & $\begin{array}{c}\text { Corrao et al. }{ }^{2} \\
(2004) \\
\text { Bagnardi et al. }{ }^{1} \\
(2001)\end{array}$ & $\begin{array}{l}1966-1998 \\
1966-2000\end{array}$ & $\begin{array}{c}13 \mathrm{CC}, 01 \mathrm{CO} ; 3233 \\
17 \mathrm{CC}, 1 \mathrm{CO} ; 7239 \\
17 \mathrm{CC}, 01 \mathrm{CO} ; 3310 \\
05 \mathrm{CC} ; 304\end{array}$ & $\begin{array}{l}9 / 11 \\
4 / 11\end{array}$ \\
\hline Laryngeal cancer & $\begin{array}{l}1.43 \\
1.35\end{array}$ & $\begin{array}{l}2.02 \\
1.83\end{array}$ & $\begin{array}{l}3.86 \\
3.24\end{array}$ & $\begin{array}{l}\text { Corrao et al. }{ }^{2} \\
(2004) \\
\text { Bagnardi et al. }{ }^{1} \\
(2001)\end{array}$ & $\begin{array}{l}1966-1998 \\
1966-2000\end{array}$ & $\begin{array}{l}20 \mathrm{CC} ; 3789 \\
20 \mathrm{CC} ; 3759\end{array}$ & $\begin{array}{l}9 / 11 \\
4 / 11\end{array}$ \\
\hline Liver cancer & $\begin{array}{c}1.19 \\
\mathrm{~T}: 1.20 \\
\mathrm{M}: 1.28 \\
\mathrm{~F}: 1.97\end{array}$ & $\begin{array}{c}1.40 \\
\mathrm{~T}: 1.41 \\
\mathrm{M}: 1.51 \\
\mathrm{~F}: 3.57\end{array}$ & $\begin{array}{c}1.81 \\
\mathrm{~T}: 1.83 \\
\mathrm{M}: 1.62 \\
\mathrm{~F}: 9.15\end{array}$ & $\begin{array}{l}\text { Corrao et al. }{ }^{2} \\
(2004) \\
\text { Bagnardi et al. }{ }^{1} \\
(2001)\end{array}$ & $\begin{array}{l}1966-1998 \\
1966-2000\end{array}$ & $\begin{array}{c}08 \mathrm{CC}, 02 \mathrm{CO} ; 1321 \\
16 \mathrm{CC}, 03 \mathrm{CO} ; 1961 \\
08 \mathrm{CC}, 02 \mathrm{CO} ; 949 \\
02 \mathrm{CC}, 01 \mathrm{CO} ; 231\end{array}$ & $\begin{array}{l}9 / 11 \\
4 / 11\end{array}$ \\
\hline Breast cancer & $\begin{array}{l}1.25 \\
1.31\end{array}$ & $\begin{array}{l}1.55 \\
1.67\end{array}$ & $\begin{array}{l}2.41 \\
2.71\end{array}$ & $\begin{array}{l}\text { Corrao et al. }{ }^{2} \\
(2004) \\
\text { Bagnardi et al. }{ }^{1} \\
(2001)\end{array}$ & $\begin{array}{l}1966-1998 \\
1966-2000\end{array}$ & $\begin{array}{l}24 \mathrm{CC}, 05 \mathrm{CO} ; 32175 \\
37 \mathrm{CC}, 12 \mathrm{CO} ; 44033\end{array}$ & $\begin{array}{l}9 / 11 \\
4 / 11\end{array}$ \\
\hline Hypertension & 1.43 & 2.04 & 4.15 & $\begin{array}{l}\text { Corrao et al. }{ }^{2} \\
\quad(2004)\end{array}$ & 1966-1998 & $02 \mathrm{CO}, 5801$ & $9 / 11$ \\
\hline Cirrhosis & 2.90 & 7.13 & 26.52 & $\begin{array}{l}\text { Corrao et al. }{ }^{2} \\
\quad(2004)\end{array}$ & 1966-1998 & 06 CC, 03 CO; 2202 & $9 / 11$ \\
\hline $\begin{array}{l}\text { Chronic } \\
\text { pancreatitis }\end{array}$ & 1.34 & 1.78 & 3.19 & $\begin{array}{l}\text { Corrao et al. }{ }^{2} \\
\quad(2004)\end{array}$ & 1966-1998 & 02 CC, 247 & $9 / 11$ \\
\hline
\end{tabular}

T: total; M: male; F: female; CC: case-control study; CO: cohort study; AMSTAR: Assessing the Methodological Quality of Systematic Reviews

* Meta-analysis used as a reference for RR. 
e Ministério da Saúde, Secretaria de Atenção à Saúde, Departamento de Regulação, Avaliação e Controle. Sistema de informações hospitalares do SUS - SIH/SUS. Brasília (DF): Datasus; 2011.

${ }^{\text {f }}$ Sistema de Informações Ambulatoriais do SUS - SIA. Suporte técnico ao Sistema de Informação Ambulatorial (SIA). Brasília (DF); s.d. [cited 2011 Aug 23]. Available from: http://sia. datasus.gov.br/principal/index.php s World Bank Group. Washington (DC); s.d [cited 2012 May 1]. Available from: http://data. worldbank.org
Data on hospital admissions and outpatient visits were extracted from the Hospital Information System (SIH-SUS) ${ }^{\mathrm{e}}$ and the Outpatient Information System (SIA-SUS)'. These open access databases provide aggregate information on the amount of money reimbursed by the government to the organizations that provide the health care (inpatient and outpatient) needed to treat and monitor these diseases.

We stratified the data by age (> 18 years), sex, type of service (inpatient or outpatient care), federated states, and year. Data were collected from 2008 to 2010 and the results reflect the average of the three years. This procedure was carried out to reduce the effect of random variation. Brazilian costs were converted into US dollars using a purchasing power parity basis: PPP 2010: US\$1.00 = R\$1.7\% .

\section{RESULTS}

The influence of alcohol consumption on the occurrence of the selected diseases, measured by PAR, showed a wide variation. The PAR estimates are presented in Tables 2 (male) and 3 ( female). On average, the smallest PAR were for liver cancer and chronic pancreatitis among male adults, and breast cancer and chronic pancreatitis for female adults. Cirrhosis showed the highest PAR for both sexes.

Table 2. Population attributable risk (PAR) for selected diseases, by Brazilian capitals (male adult population).

\begin{tabular}{|c|c|c|c|c|c|c|c|}
\hline \multirow[t]{2}{*}{ Capital } & $\begin{array}{c}\text { Laryngeal } \\
\text { cancer }\end{array}$ & $\begin{array}{c}\text { Oropharyngeal } \\
\text { cancer }\end{array}$ & $\begin{array}{c}\text { Esophageal } \\
\text { cancer }\end{array}$ & Liver cancer & Hypertension & Cirrhosis & $\begin{array}{c}\text { Chronic } \\
\text { pancreatitis }\end{array}$ \\
\hline & PAR (\%) & PAR (\%) & PAR (\%) & PAR (\%) & PAR (\%) & PAR (\%) & PAR (\%) \\
\hline Porto Velho & 4.98 & 8.75 & 4.17 & 3.03 & 4.58 & 17.48 & 3.65 \\
\hline Rio Branco & 4.98 & 8.75 & 4.17 & 3.03 & 4.58 & 17.48 & 3.65 \\
\hline Manaus & 5.74 & 10.03 & 4.81 & 3.50 & 5.28 & 19.76 & 4.22 \\
\hline Boa Vista & 4.98 & 8.75 & 4.17 & 3.03 & 4.58 & 17.48 & 3.65 \\
\hline Belem & 4.98 & 8.75 & 4.17 & 3.03 & 4.58 & 17.48 & 3.65 \\
\hline Macapa & 4.98 & 8.75 & 4.17 & 3.03 & 4.58 & 17.48 & 3.65 \\
\hline Palmas & 4.68 & 8.25 & 3.92 & 2.84 & 4.30 & 16.57 & 3.43 \\
\hline Sao Luis & 7.71 & 13.26 & 6.48 & 4.74 & 7.10 & 25.24 & 5.70 \\
\hline Teresina & 7.45 & 12.84 & 6.26 & 4.58 & 6.86 & 24.56 & 5.50 \\
\hline Fortaleza & 7.96 & 13.66 & 6.69 & 4.90 & 7.33 & 25.89 & 5.88 \\
\hline Natal & 7.10 & 12.27 & 5.97 & 4.36 & 6.54 & 23.61 & 5.24 \\
\hline Joao Pessoa & 7.19 & 12.42 & 6.04 & 4.41 & 6.62 & 23.86 & 5.31 \\
\hline Recife & 9.20 & 15.64 & 7.76 & 5.69 & 8.48 & 29.06 & 6.83 \\
\hline Maceio & 7.45 & 12.84 & 6.26 & 4.58 & 6.86 & 24.56 & 5.50 \\
\hline Aracaju & 5.61 & 9.80 & 4.70 & 3.42 & 5.16 & 19.37 & 4.12 \\
\hline Salvador & 7.45 & 12.84 & 6.26 & 4.58 & 6.86 & 24.56 & 5.50 \\
\hline Belo Horizonte & 6.78 & 11.74 & 5.69 & 4.15 & 6.24 & 22.72 & 5.00 \\
\hline Vitoria & 7.53 & 12.97 & 6.33 & 4.63 & 6.94 & 24.77 & 5.56 \\
\hline Rio de Janeiro & 6.05 & 10.54 & 5.07 & 3.69 & 5.56 & 20.65 & 4.45 \\
\hline Sao Paulo & 3.68 & 6.53 & 3.07 & 2.22 & 3.37 & 13.37 & 2.69 \\
\hline Curitiba & 3.74 & 6.63 & 3.12 & 2.26 & 3.43 & 13.57 & 2.73 \\
\hline Florianopolis & 2.46 & 4.41 & 2.05 & 1.48 & 2.25 & 9.24 & 1.79 \\
\hline Porto Alegre & 4.26 & 7.52 & 3.56 & 2.58 & 3.91 & 15.24 & 3.12 \\
\hline Campo Grande & 4.24 & 7.50 & 3.55 & 2.57 & 3.90 & 15.19 & 3.11 \\
\hline Cuiaba & 4.24 & 7.50 & 3.55 & 2.57 & 3.90 & 15.19 & 3.11 \\
\hline Goiania & 4.24 & 7.50 & 3.55 & 2.57 & 3.90 & 15.19 & 3.11 \\
\hline Brasilia & 6.02 & 10.49 & 5.04 & 3.67 & 5.53 & 20.56 & 4.43 \\
\hline
\end{tabular}


Table 4 presents the total costs of the selected diseases, stratified by sex. Of the US $\$ 344$ million spent on outpatient and inpatient care, $2.4 \%$ was attributable to alcohol consumption ( $\geq 25 \mathrm{~g} /$ day of ethanol). The total costs of these diseases were three times higher for women than for men. However, this pattern changed when the fraction attributable to alcohol consumption was considered, with men being responsible for more than $2 / 3$ of the costs.

When these costs were separately analyzed for in- and outpatient care, other patterns were observed. The total costs of hospitalization (Table 4) for the selected diseases were similar between men and women. However, the costs attributable to alcohol consumption were almost six times higher for the male group. For ambulatory services (Table 4), the total costs related to alcohol consumption were less similar between men and women than that observed for the hospitalization data. However, although women account for more than $80.0 \%$ of total costs for the selected diseases, this figure was reduced to $40.0 \%$ when the fraction attributable to alcohol consumption was considered.

The cost analysis by disease showed that oropharyngeal cancer, breast cancer, and cirrhosis were responsible for $34.0 \%, 20.0 \%$, and $15.0 \%$ of the costs, respectively (Table 5). The first two diseases were also responsible for the larger proportion of costs in ambulatory services, while the relative impact of breast cancer on hospital costs was small. The most important diseases for hospital costs were cirrhosis and oropharyngeal cancer, followed by hypertension.

The costs attributed to alcohol in all selected diseases represented $0.38 \%$ of Brazilian gross domestic product.

Table 3. Population attributable risk (PAR) for selected diseases, by Brazilian capitals (female adult population).

\begin{tabular}{|c|c|c|c|c|c|c|c|c|}
\hline \multirow[t]{2}{*}{ Capital } & $\begin{array}{c}\text { Laryngeal } \\
\text { cancer }\end{array}$ & $\begin{array}{c}\text { Oropharyngeal } \\
\text { cancer }\end{array}$ & $\begin{array}{c}\text { Esophageal } \\
\text { cancer } \\
\end{array}$ & $\begin{array}{l}\text { Breast } \\
\text { cancer }\end{array}$ & $\begin{array}{c}\text { Liver } \\
\text { cancer }\end{array}$ & Hypertension & Cirrhosis & $\begin{array}{c}\text { Chronic } \\
\text { pancreatitis }\end{array}$ \\
\hline & PAR (\%) & PAR (\%) & PAR (\%) & PAR (\%) & PAR (\%) & PAR (\%) & PAR (\%) & PAR (\%) \\
\hline Porto Velho & 1.47 & 2.66 & 1.23 & 0.66 & 2.99 & 1.35 & 5.70 & 1.07 \\
\hline Rio Branco & 1.47 & 2.66 & 1.23 & 0.66 & 2.99 & 1.35 & 5.70 & 1.07 \\
\hline Manaus & 1.47 & 2.66 & 1.23 & 0.66 & 2.99 & 1.35 & 5.70 & 1.07 \\
\hline Boa Vista & 1.47 & 2.66 & 1.23 & 0.66 & 2.99 & 1.35 & 5.70 & 1.07 \\
\hline Belem & 1.82 & 3.28 & 1.51 & 0.82 & 3.68 & 1.67 & 6.96 & 1.32 \\
\hline Macapa & 1.47 & 2.66 & 1.23 & 0.66 & 2.99 & 1.35 & 5.70 & 1.07 \\
\hline Palmas & 1.38 & 2.49 & 1.15 & 0.62 & 2.80 & 1.26 & 5.34 & 1.00 \\
\hline Sao Luis & 4.02 & 7.11 & 3.35 & 1.83 & 7.95 & 3.69 & 14.46 & 2.94 \\
\hline Teresina & 2.26 & 4.06 & 1.88 & 1.02 & 4.55 & 2.07 & 8.54 & 1.64 \\
\hline Fortaleza & 2.44 & 4.38 & 2.04 & 1.11 & 4.92 & 2.24 & 9.20 & 1.78 \\
\hline Natal & 2.16 & 3.88 & 1.80 & 0.98 & 4.36 & 1.98 & 8.20 & 1.57 \\
\hline Joao Pessoa & 0.92 & 1.67 & 0.77 & 0.41 & 1.88 & 0.84 & 3.63 & 0.67 \\
\hline Recife & 2.35 & 4.23 & 1.96 & 1.07 & 4.74 & 2.16 & 8.88 & 1.71 \\
\hline Maceio & 2.26 & 4.06 & 1.88 & 1.02 & 4.55 & 2.07 & 8.54 & 1.64 \\
\hline Aracaju & 1.99 & 3.58 & 1.66 & 0.90 & 4.02 & 1.82 & 7.59 & 1.45 \\
\hline Salvador & 2.26 & 4.06 & 1.88 & 1.02 & 4.55 & 2.07 & 8.54 & 1.64 \\
\hline Belo Horizonte & 3.32 & 5.91 & 2.77 & 1.51 & 6.61 & 3.04 & 12.18 & 2.42 \\
\hline Vitoria & 3.66 & 6.50 & 3.06 & 1.67 & 7.28 & 3.36 & 13.32 & 2.68 \\
\hline Rio de Janeiro & 2.84 & 5.09 & 2.37 & 1.29 & 5.70 & 2.61 & 10.58 & 2.07 \\
\hline Sao Paulo & 1.11 & 2.01 & 0.92 & 0.50 & 2.26 & 1.01 & 4.33 & 0.80 \\
\hline Curitiba & 0.80 & 1.46 & 0.67 & 0.36 & 1.64 & 0.73 & 3.16 & 0.58 \\
\hline Florianopolis & 1.90 & 3.42 & 1.58 & 0.86 & 3.84 & 1.74 & 7.26 & 1.38 \\
\hline Porto Alegre & 2.56 & 4.58 & 2.13 & 1.16 & 5.13 & 2.34 & 9.59 & 1.86 \\
\hline Campo Grande & 2.08 & 3.73 & 1.73 & 0.94 & 4.19 & 1.90 & 7.89 & 1.51 \\
\hline Cuiaba & 2.08 & 3.73 & 1.73 & 0.94 & 4.19 & 1.90 & 7.89 & 1.51 \\
\hline Goiania & 2.08 & 3.73 & 1.73 & 0.94 & 4.19 & 1.90 & 7.89 & 1.51 \\
\hline Brasilia & 1.75 & 3.15 & 1.45 & 0.79 & 3.54 & 1.60 & 6.70 & 1.27 \\
\hline
\end{tabular}


Table 4. Hospitalization, ambulatory, and total costs with estimated attributable costs of alcohol consumption ${ }^{\mathrm{a}}$ related-diseases.

\begin{tabular}{|c|c|c|c|c|c|}
\hline $\begin{array}{l}\text { Hospitalization } \\
\text { costs (US\$) }\end{array}$ & $\begin{array}{l}\text { Hospitalization costs } \\
\text { (US\$) attributable to } \\
\text { risk factors }(\%)\end{array}$ & $\begin{array}{c}\text { Ambulatory costs } \\
\text { (US\$) }^{\mathrm{b}} \\
\text { (medical visits, }^{\text {exams, procedures) }}\end{array}$ & $\begin{array}{l}\text { Ambulatory costs } \\
\text { (US\$) attributable } \\
\text { to risk factors (\%) }\end{array}$ & $\begin{array}{l}\text { Total costs (US\$) } \\
\text { Outpatient and } \\
\text { Inpatient care }\end{array}$ & $\begin{array}{l}\text { Total costs (US\$) } \\
\text { attributable to risk } \\
\text { factors }(\%)\end{array}$ \\
\hline \multicolumn{2}{|c|}{ Women } & \multicolumn{2}{|c|}{ Women } & \multicolumn{2}{|c|}{ Women } \\
\hline 41,6 million & 571,3 thousand $(1.37 \%)$ & 218,2 million & 1,7 million $(0.82 \%)$ & 259,8 million & 2,3 million $(0.91 \%)$ \\
\hline \multicolumn{2}{|c|}{ Men } & \multicolumn{2}{|c|}{ Men } & \multicolumn{2}{|c|}{ Men } \\
\hline 42,7 million & 3,2 million $(7.67 \%)$ & 41,5 million & 2,6 million $(6.33 \%)$ & 84,2 million & 5,9 million $(7.01 \%)$ \\
\hline \multicolumn{2}{|c|}{ Total } & \multicolumn{2}{|c|}{ Total } & \multicolumn{2}{|c|}{ Total } \\
\hline 84,3 million & 3,8 million $(4,56 \%)$ & 259,7 million & 4,4 million $(1.70 \%)$ & 344,1 million & 8,2 million $(2.40 \%)$ \\
\hline
\end{tabular}

a $25 \mathrm{~g} /$ day or more of ethanol.

b Three years average (2008-2010) of costs related to selected diseases (see Method's section). Costs in Dollar PPP-2010.

Table 5. Attributable costs by alcohol consumption ${ }^{\mathrm{a}}$ related-diseases in the Brazilian Unified Health System.

\begin{tabular}{lccc}
\hline Disease & $\begin{array}{c}\text { Hospitalization costs } \\
\text { US\$ }\end{array}$ & $\begin{array}{c}\text { Ambulatory costs } \\
\text { US } \$\end{array}$ & $\begin{array}{c}\text { Total } \\
\text { US } \$\end{array}$ \\
\hline Breast cancer & 136,1 thousand & 1,4 million & 1,6 million \\
Oropharyngeal cancer & 1,1 million & 1,6 million & 2,7 million \\
Laryngeal cancer & 277,5 thousand & 367,4 thousand & 645,0 thousand \\
Esophageal cancer & 368,4 thousand & 385,2 thousand & 753,6 thousand \\
Liver cancer & 70,8 thousand & 21,9 thousand & 92,8 thousand \\
Hypertension & 630,8 thousand & 443,4 thousand & 1 million \\
Cirrhosis & 1,2 million & 10,0 thousand & 1,2 million \\
Chronic pancreatitis & 18,5 thousand & 24,4 thousand & 42,9 thousand \\
Total & 3,8 million & 4,4 million & 8,2 million \\
\hline
\end{tabular}

25 g/day or more of ethanol.

b Three years average (2008-2010) of costs related to selected diseases (see Method's section). Costs in Dollar PPP-2010.

\section{DISCUSSION}

The estimates of the PAR showed a wide variation, but when data were analyzed both by capitals or sex, cirrhosis consistently had the largest PAR, followed by oropharyngeal cancer. Liver cancer showed a PAR similar to oropharyngeal cancer among women.

The average annual costs for the eight selected alcohol-related diseases were estimated at US\$8 million. Treatment of men contributed significantly more to these costs, mainly because of the hospital sector. Thavorncharoensap et al. ${ }^{10}$ also reported a larger contribution of men to health care costs for alcohol related diseases in Thailand. Those authors observed that hospitalizations contributed slightly more than outpatient services, while in our study we observed the inverse. In Sweden, Jarl et al. ${ }^{4}$ found that around one-third of the health care costs in 2002 for the treatment of alcohol-related diseases derived from inpatients. The other two-thirds were equally shared by outpatients and primary care.

Comparing the health care costs found in our study with other studies is difficult due to several factors. In the systematic review carried out by Thavorncharoensap et al. ${ }^{9}$ (2009), studies were excluded for, among other reasons, not being published in English or if a full description of publication could not be retrieved. Their review found 20 studies that met their criteria, with 12 conducted in developed countries and only one in a developing country (Thailand). Their list of included diseases was larger than ours. For example, several studies included mental and behavioral disorders, injuries, poisoning, and external causes. Moreover, there were important differences in the economic and health care infrastructures, since nearly all these studies were carried out in developed countries. 
Although in our study cirrhosis had the largest PAR for men and women, it reached the third position for attributable costs. Despite having a much smaller PAR than cirrhosis, oropharyngeal cancer occupied the first position for the costs impacting both hospital and ambulatory sectors. Breast cancer gave the second highest contribution for the costs, mainly because of the ambulatory sector.

Some limitations in our study need to be addressed, most of them resulting from the lack of information for the Brazilian population. First, PAR was estimated using RR estimated by meta-analyses with data from prospective and case-control studies carried out in high income countries. Our assumption is that the effect of alcohol consumption on the risk of the selected diseases is relatively homogeneous among western populations. We estimated PAR based on the RR for a consumption of $25 \mathrm{~g} /$ day of ethanol, since the Brazilian survey only provided information on the percentage of adults consuming one or more drinks for women ( $15 \mathrm{~g} /$ day of ethanol) and two or more drinks for men ( $30 \mathrm{~g} /$ day of ethanol). However, the probable impact of this decision is a small underestimation of the risk. Second, we had to assume that confounding factors were controlled when RR were estimated in order to interpret PAR as the proportion of cases that could be prevented if the exposure were eliminated. However, we have no information on how most of the individual studies included in the metaanalyses dealt with this methodological aspect. Third, we did not use exposure by age groups, since precise estimates were unavailable. Finally, the Departamento de Informática do Sistema Unico de Saúde (DATASUS - Information Technology Department of the Brazilian Unified Health System) is an administrative database, designed to make and record payments for hospitalizations, rather than for epidemiological purposes. Many limitations regarding this data can be raised such as the quality of the input data, fraud, and duplication of data.

Another limitation concerns the findings of benefits related to moderate consumption of alcohol (e.g., coronary heart diseases) in some studies. Excluding these diseases from the analysis could have overestimated the costs.

The consumption pattern of alcohol in Brazil has been classified as being at a high-risk level ${ }^{6}$. To the best of our knowledge, this is the first study to estimate health care costs of relevant alcohol-related diseases in the SUS. This information is needed not only to improve the estimates of health care costs, but also to quantify the scale of the burden attributable to alcohol consumption on the health system and on society.

\section{REFERENCES}

1. Bagnardi V, Blangiardo M, La Vecchia C, Corrao G. Alcohol consumption and the risk of cancer: a meta-analysis. Alcohol Res Health. 2001;25(4):263-70.

2. Corrao G, Bagnardi V, Zambon A, La Vecchia C. A meta-analysis of alcohol consumption and the risk of 15 diseases. Prev Med. 2004;38(5):613-9. DOl:10.1016/j.ypmed.2003.11.027

3. Islami F, Tramacere I, Rota M, Bagnardi V, Fedirko V, Scotti L et al. Alcohol drinking and laryngeal cancer: overall and dose-risk relation: a systematic review and meta-analysis. Oral Oncol. 2010;46(11):802-10. DOI:10.1016/j.oraloncology.2010.07.015

4. Jarl J, Johansson P, Eriksson A, Eriksson M, Gerdtham UG, Hemström O et al. The societal cost of alcohol consumption: an estimation of the economic and human cost including health effects in Sweden 2002. Eur J Health Econ. 2008;9(4):351-60. DOI:10.1007/s10198-007-0082-1

5. Levin ML. The occurrence of lung cancer in man. Acta Unio Int Contra Cancrum. 1953;9(3):531-41.

6. Meloni JN, Laranjeira R. Custo social e de saúde do consumo do álcool. Rev Bras Psiquiatr. 2004;26 Supl 1:7-10. DOI:10.1590/S1516-44462004000500003

7. Room R, Babor T, Rehm J. Alcohol and public health. Lancet. 2005;365(9458):519-30. DOI:10.1016/s0140-6736(05)17870-2

8. Shea BJ, Hamel C, Wells GA, Bouter LM, Kristjansson E, Grimshaw J et al. AMSTAR is a reliable and valid measurement tool to assess the methodological quality of systematic reviews. J Clin Epidemiol. 2009;62(10):1013-20. DOI:10.1016/j.jclinepi.2008.10.009 
9. Thavorncharoensap $M$, Teerawattananon Y, Yothasamut J, Lertpitakpong C, Chaikledkaew U. The economic impact of alcohol consumption: a systematic review. Subst Abuse Treat Prev Policy. 2009;4:20. DOI:10.1186/1747-597x-4-20

10. Thavorncharoensap M, Teerawattananon Y, Yothasamut J, Lertpitakpong C, Thitiboonsuwan K, Neramitpitagkul $P$ et al. The economic costs of alcohol consumption in Thailand, 2006. BMC Public Health. 2010;10:323. DOI:10.1186/1471-2458-10-323

Funding: Instituto de Avaliação de Tecnologia em Saúde (IATS - Projeto CNPq 573826/2008-0). ESFC was partially funded by Conselho Nacional de Desenvolvimento Científico e Tecnológico (CNPq - Process 302.269/2008-8).

Author's Contribution: Conceptualization: LB, ESFC, DVA. Design:LB, ESFC, DVA. Data analysis and interpretation: LB, ESFC, DVA. Contribution for data collection, analysis, and interpretation: LAB, GAA, TAM, PCR. Manuscript elaboration: LB, ESFC, DVA, LAB, GAA, TAM, PCR. All the authors approved the final version of the article.

Acknowledgments: To Dr. André Szklo, of the Brazilian National Cancer Institute (INCA), for providing data on alcohol consumption separately according to sex.

Conflict of Interest: The authors declare no conflict of interest. 